Western North American Naturalist 70(2), (C) 2010, pp. 249-251

\title{
STATUS OF AN INVADING MAINLAND JACKRABBIT ON CERRALVO ISLAND, GULF OF CALIFORNIA
}

\author{
Consuelo Lorenzo ${ }^{1}$, Sergio Ticul Álvarez-Castañeda ${ }^{2,3}$, Patricia Cortés-Calva ${ }^{2}$, \\ Mayra de la Paz ${ }^{2}$,and Jorge E. Bolaños ${ }^{1}$
}

\begin{abstract}
We report the first observations of the black-tailed jackrabbit (Lepus californicus) on Cerralvo Island, Baja California Sur, Mexico. Evidence suggests a self-sustaining population. Analysis of available records indicates no previous record of Lepus on the island. Introduction of the jackrabbit to the island appears to have occurred between 1960 and 1991.
\end{abstract}

Key words: jackrabbit, island, human introduction, native species, Gulf of California, Mexico.

The black-tailed jackrabbit (Lepus californicus) occupies the northwestern part of Mexico, including the Baja California Peninsula (Ramírez-Pulido et al. 1983). Four known mainland subspecies of L. californicus (L. c. xanti, L. c. martirensis, L. c. bennettii, and L. c. deserticola) and 2 island endemic subspecies $(L . c$. sheldoni, Carmen Island; and L. c. magdalenae, Magdalena and Margarita islands) occur on the peninsula. The populations of $L$. c. sheldoni and L. c. magdalenae are on the Mexican list of endangered species (NOM-059-SEMARNAT2001, SEMARNAT 2002). Last year, we began to review the status of populations of Lagomorpha on the islands around the Baja California Peninsula. Previous surveys of Cerralvo Island indicated possible presence of L. californicus, but the species had not been definitively documented on the island. We surveyed the island to determine if this species was present.

Cerralvo Island, the southernmost island in the Gulf of California, is located off the Cape Region of the southern end of the peninsula. It is the fifth largest island in the Gulf of California, about $140 \mathrm{~km}^{2}$ (Murphy et al. 2002), and is $11 \mathrm{~km}$ from the peninsula (Álvarez-Castañeda and Patton 1999). The only native mammal species recorded for the island are Chaetodipus arenarius siccus and Peromyscus eremicus avius (Álvarez-Castañeda and Cortés-Calva 1999, Lawlor et al. 2002). The vegetation consists of trees, bushes, and perennials; and the most common genera are Euphorbia, Perityle,
Opuntia, Porophyllum, Mammillaria, Bursera, and Boerhaavia (León de la Luz and Rebman 2002). Most of the island is hilly and deeply dissected by narrow canyons; less than 5\% has a slope under $50 \%$. The island also has a small population of domestic cats (Felis sylvestris).

We conducted our first survey on 26-28 February 2009 by walking random transects (approximately $6 \mathrm{~km}$ ) at an average of $2 \mathrm{~km} \cdot \mathrm{h}^{-1}$ from 5:00 to 8:00 (morning) and from 18:00 to 21:00 (evening). During the evening hours, we used headlamps. In a localized area $\left(24.160^{\circ} \mathrm{N}\right.$, $109.875^{\circ} \mathrm{W}$ and $24.150^{\circ} \mathrm{N}, 109.865^{\circ} \mathrm{W}$ ), we saw 14 jackrabbits (Fig. 1). Twelve jackrabbits were observed in flat, sandy habitat, and only 2 were seen on high-gradient slopes. We also found a large amount of feces and numerous resting beds of black-tailed jackrabbits.

A second survey was conducted on 3-5 June 2009. Four specimens were collected, an additional 2 specimens were observed, and 16 skulls and skeletons were found (Table 1, Fig. 1). Three skulls or skeletons were found in scrub vegetation habitat on the southern side of the island in association with Cyrtocarpa edulis (wild plum), Jatropha cuneata (limberbush), Cylindropuntia cholla (cholla), Colubrina glabra, and Phaulothamnus spinescens (putia). Thirteen skulls or skeletons of jackrabbits were found in sandy habitat with coastal vegetation composed of Hyptis emoryi (salvia), Jouvea pilosa (tropical grass), Euphorbia leucophylla (spurge), Lycium brevipes (wolfberry), Condalia globosa (bitter

${ }^{1}$ El Colegio de la Frontera Sur (ECOSUR), Departamento Ecología y Sistemática Terrestres, Área Conservación de la Biodiversidad, Carretera Panameri cana y Periférico Sur s/n, San Cristóbal de Las Casas, Chiapas 29290, México.

${ }^{2}$ Centro de Investigaciones Biológicas del Noroeste (CIBNOR), Mar Bermejo 195, Col. Playa Palo de Santa Rita, La Paz, Baja California Sur 23090, México. ${ }^{3}$ Corresponding author. E-mail: sticul@ cibnormx 


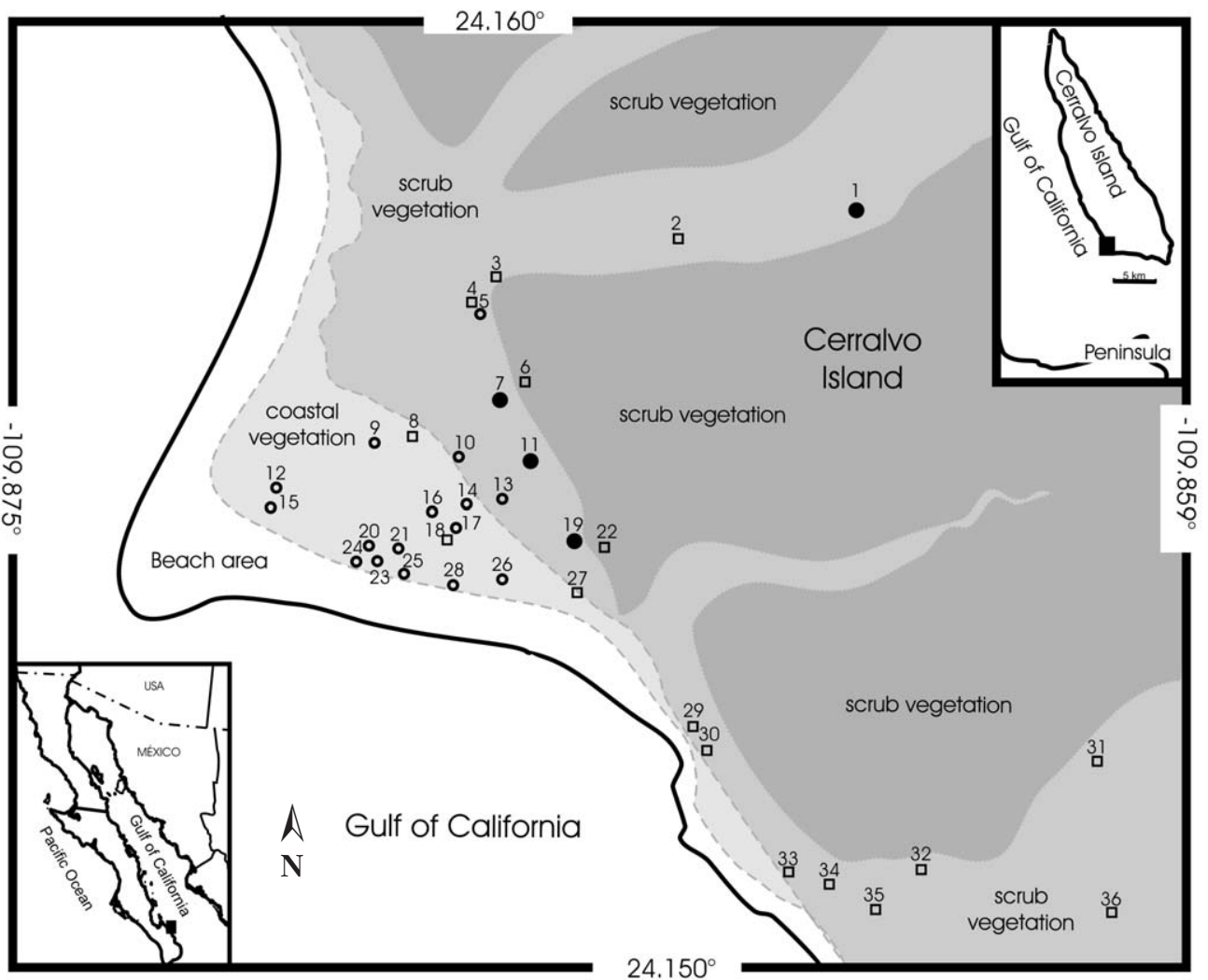

Fig. 1. Map of Cerralvo Island showing the places where specimens of Lepus californicus were observed (open squares) and collected (solid circles) and where skulls of Lepus were found (open circles). Three habitat types on the island are sandy areas with coastal vegetation (light gray), alluvial areas with scrub vegetation (medium gray), and slopes with scrub vegetation (dark gray).

TABLE 1. List of specimens and skulls for the black-tailed jackrabbit (Lepus californicus) found on Cerralvo Island, Baja California Sur, Mexico. Localities (Loc) by number are shown in Figure 1. Latitudes and longitudes are north and west, respectively, and are in decimal degrees.

\begin{tabular}{|c|c|c|c|c|c|c|c|}
\hline Loc & Record & Latitude & Longitude & Loc & Record & Latitude & Longitude \\
\hline 1 & Collected Lepus & 24.1573 & -109.8632 & 19 & Collected Lepus & 24.1535 & -109.8672 \\
\hline 2 & Observed Lepus & 24.1573 & -109.8659 & 20 & Skull Lepus & 24.1534 & -109.8701 \\
\hline 3 & Observed Lepus & 24.1566 & -109.8683 & 21 & Skull Lepus & 24.1534 & -109.8697 \\
\hline 4 & Observed Lepus & 24.1562 & -109.8686 & 22 & Observed Lepus & 24.1533 & -109.8671 \\
\hline 5 & Skull Lepus & 24.1562 & -109.8686 & 23 & Skull Lepus & 24.1533 & -109.8700 \\
\hline 6 & Observed Lepus & 24.1556 & -109.8680 & 24 & Skull Lepus & 24.1532 & -109.8702 \\
\hline 7 & Collected Lepus & 24.1552 & -109.8682 & 25 & Skull Lepus & 24.1531 & -109.8697 \\
\hline 8 & Observed Lepus & 24.1547 & -109.8697 & 26 & Skull Lepus & 24.1530 & -109.8684 \\
\hline 9 & Skull Lepus & 24.1547 & -109.8700 & 27 & Observed Lepus & 24.1529 & -109.8676 \\
\hline 10 & Skull Lepus & 24.1545 & -109.8689 & 28 & Skull Lepus & 24.1529 & -109.8690 \\
\hline 11 & Collected Lepus & 24.1545 & -109.8678 & 29 & Observed Lepus & 24.1511 & -109.8656 \\
\hline 12 & Skull Lepus & 24.1541 & -109.8714 & 30 & Observed Lepus & 24.1509 & -109.8654 \\
\hline 13 & Skull Lepus & 24.1540 & -109.8683 & 31 & Observed Lepus & 24.1508 & -109.8598 \\
\hline 14 & Skull Lepus & 24.1540 & -109.8689 & 32 & Observed Lepus & 24.1493 & -109.8623 \\
\hline 15 & Skull Lepus & 24.1540 & -109.8714 & 33 & Observed Lepus & 24.1492 & -109.8644 \\
\hline 16 & Skull Lepus & 24.1538 & -109.8692 & 34 & Observed Lepus & 24.1491 & -109.8636 \\
\hline 17 & Skull Lepus & 24.1535 & -109.8691 & 35 & Observed Lepus & 24.1488 & -109.8629 \\
\hline 18 & Observed Lepus & 24.1535 & -109.8692 & 36 & Observed Lepus & 24.1488 & -109.8596 \\
\hline
\end{tabular}


snakewood), Colubrina glabra (coulubrina), Jatropha cuneata (limberbush), and Cylindropuntia cholla (cholla). Specimens have the diagnostic characteristics of L. californicus, and their collection constitutes the first record of this species on Cerralvo Island. All the specimens are housed in the mammal collection of Centro de Investigaciones Biológicas del Noroeste (CIB 15512 to 15515$)$. Specific collection locales are given in Table 1.

The first recorded mammal survey on Cerralvo Island was made by Nelson and Goldman (11-13 February 1906), when the type specimens of Chaetodipus arenarius siccus (Osgood 1907) and Peromyscus eremicus avius (Osgood 1909) were collected. Lepus was not reported by Goldman (1951). From 1906 to 1960, Cerralvo Island was surveyed 39 times for terrestrial vertebrates (Banks 1964), and in none of these surveys was L. californicus recorded. Given this relatively large number of surveys, we believe that the introduction of jackrabbits occurred between 1960 and 1991, the latter year being when S.T. Álvarez-Castañeda (second author) first found tracks of jackrabbits. We have no information on how jackrabbits arrived on the island. The most plausible explanation is intentional introduction by a resident on the peninsula.

We thank M. Cota for valuable aid in the field. Funds were provided by Consejo Nacional de Ciencia y Tecnología (CONACYT grants I25251N, 39467Q, SEMARNAP-2002-CO10193).

\section{Literature Cited}

Álvarez-Castañeda, S.T., and P. Cortés-Calva. 1999. Familia Muridae. Pages 445-566 in S.T. Álvarez-
Castañeda and J.L. Patton, editors, Mamíferos del Noroeste Mexicano. Centro de Investigaciones Biológicas del Noroeste, La Paz, Baja California Sur, México.

Álvarez-Castañeda, S.T. and J.L. Patton. 1999. Mamíferos del Noroeste de México. Centro de Investigaciones Biológicas del Noroeste, La Paz, Baja California Sur, México.

BANKs, R.C. 1964. The mammals of Cerralvo Island, Baja California. Transactions of the San Diego Society of Natural History 13:397-404.

Goldman, E.A. 1951. Biological investigations in Mexico. Smithsonian Miscellaneous Collections 115:1-476.

Lawlor, T.E., D.J. Hafner, P. Stapp, B.R. Riddle, and S.T. ÁlvarEZ-Castañeda. 2002. The mammals. Pages 326-361 in T.J. Case, M.L. Cody, and E. Ezcurra, editors, A new island biogeography of the Sea of Cortéz. 2nd edition. Oxford University Press, New York, NY.

LeÓn DE LA LuZ, J.L., AND J. Rebman. 2002. The vascular flora of Cerralvo Island. Pages 512-526 in T.J. Case, M.L. Cody and E. Ezcurra, editors, A new island biogeography of the Sea of Cortés. 2nd edition. Oxford University Press, New York, NY.

Murphy, R.W., F. Sanchez-Piñedo, G.A. Polis, and R.L. ALBu. 2002. New measurements of area and distances for islands in the Sea of Cortés. Pages 447-464 in T.J. Case, M.L. Cody, and E. Ezcurra, editors, A new island biogeography of the Sea of Cortés. 2nd edition. Oxford University Press, New York, NY.

OsGood, W.H. 1907. Four new pocket mice. Proceedings of the Biological Society of Washington 20:19-21.

1909. Revision of the mice of the American genus Peromyscus. North American Fauna 28:1-285.

Ramírez-Pulido, J., R.L. Wilchis, C. Müdespacher, AND I.E. LIRA. 1983. Lista y bibliografía reciente de los mamíferos de México. Universidad Autónoma Metropolitana-Iztapalapa, DF, México.

SEMARNAT. 2002. Proyecto de Norma Oficial Mexicana Proy-NOM-059-Ecol-2001 Protección Ambiental Especies nativas de México de flora y fauna silvestres-categorías de riesgo y especificaciones para su inclusión, exclusión o cambio Lista de especies en riesgo 6 de marzo 2002 Diario Oficial de la Federación, Mexico City.

Received 4 September 2009 Accepted 5 March 2010 